\title{
Adrenal Cortex Carcinoma
}

National Cancer Institute

\section{Source}

National Cancer Institute. Adrenal Cortex Carcinoma. NCI Thesaurus. Code C9325.

A rare, usually large (greater than $5 \mathrm{~cm}$ ), malignant epithelial tumor arising from the adrenal cortical cells. Symptoms are usually related to the excessive production of hormones, and include Cushing's syndrome and virilism in women. Common sites of metastasis include liver, lung, bone, and retroperitoneal lymph nodes. Advanced radiologic procedures have enabled the detection of small tumors, resulting in the improvement of the 5-year survival. 